\title{
Demographic variables and stock status of pike, Esox lucius, in the commercial fishery in the Anzali Wetland (SW Caspian Sea) near the southern limits of its distribution range
}

\author{
Mehdi Moslemi-Aqdam ${ }^{1, *}$, Javid Imanpour Namin ${ }^{1}$, Masoud Sattari ${ }^{1}$, Jyrki Lappalainen ${ }^{2}$ \\ and Mikko Olin ${ }^{2}$ \\ ${ }^{1}$ Fisheries Department, Faculty of Natural Resources, University of Guilan, P.O. Box 1144, Sowmeh-sara, Iran \\ 2 Department of Environmental Science, University of Helsinki, Helsinki, Finland
}

Received 9 July 2016 / Accepted 16 January 2017

\begin{abstract}
The demographic variables of pike (Esox lucius) were studied at the southern edge of the species' distribution in the Anzali Wetland, south-western Caspian Sea. The main aim was to provide data for the assessment of the stock and to explore possible fisheries management measures such as setting minimum landing size based on length-at-maturity. Pike collected from commercial landings ranged from 15.4 to $75.4 \mathrm{~cm}$ in fork length (FL), from 52.9 to $3462.5 \mathrm{~g}$ in weight and were between 0 and 8 years old. Von Bertalanffy growth function parameters were $L_{\infty}=90.6 \mathrm{~cm} \mathrm{FL}, k=0.12 \mathrm{yr}^{-1}$ and $t_{0}=-1.74 \mathrm{yr}^{-1}$. Male pike matured at $1-2$ years with $L_{50}$ of $28.6 \mathrm{~cm} \mathrm{FL}$, whereas females matured at 2-3 years with a $L_{50}$ of $33.9 \mathrm{~cm}$ FL. Instantaneous total mortality $(Z)$ was estimated as $0.93 \mathrm{yr}^{-1}$, while fishing mortality $(F)$ was estimated to be $0.66 \mathrm{yr}^{-1}$. Yield-per-recruit analysis indicated that pike in the Anzali Wetland seems to be growthoverfished under the current fishing regime with no management measures, and substantial increases in yield could be achieved by increasing the length at first harvest. The results indicated that management actions such as enforced legislation are required to obtain a better stock status and higher yield. Management could be more effective if the number of fishers and their catch could be controlled, e.g., through the allocation of fishing licenses.
\end{abstract}

Keywords: Growth / Maturity / Maximum sustainable yield / Mortality / Overfishing / Yield-per-recruit

\section{Introduction}

Demographic measures are crucial to understanding the dynamics of fish populations, thus, estimation of demographic parameters is at the very core of ecological research and management (Walters and Martell, 2004). Variation in life history traits such as growth, size and age-at-maturity, sexratio or fecundity affects recruitment, and thereby also population size and recovery rates (Ratner and Lande, 2001; Hutchings, 2005). Length- and age-at-maturity are important reference points in fishery management (Hilborn and Walters, 1992). These growth-related life history traits are connected both to local anthropogenic activities such as fishing pressure (Law, 2000; Heino and Godø, 2002; Bradford et al., 2009) and to environmental factors including temperature and food availability (Newman et al., 2000; Robertson et al., 2005; Durieux et al., 2009; Tolan and Fisher, 2009). Hence, demographic parameters vary greatly among species and populations (Kuparinen et al., 2016).

\footnotetext{
* Corresponding author: mehdimoslemiaqdam@gmail.com
}

Pike, Esox lucius, is considered a keystone species in freshwater and brackish ecosystems, and commonly supports commercial and recreational fisheries (Raat, 1988; Craig, 1996; Paukert et al., 2001). It is a mesothermal, cool water species (Casselman, 1996) and widely distributed across the northern hemisphere (Nelson, 2006). Habitat conditions (e.g., water temperature) may be unfavorable for pike in southern parts of its range (Casselman, 1978; Bevelheimer et al., 1985; Neumann et al., 1994). One of the most southerly populations is found in the Caspian Sea (Crossman, 1996; Senanan and Kapuscinski, 2000). Although the life history of pike has been intensively studied in high latitudes, few detailed studies have been conducted in areas situated close to the southern limit of its distribution range (Lorenzoni et al., 2002; Çubuk et al., 2005; Koch and Steffensen, 2013; Scheibel et al., 2016). Therefore, the first aim of this study was to provide data on the life history of pike near the southern limit.

The Anzali Wetland along the southwest shore of the Caspian Sea is considered the main habitat for pike in Iran (Sattari et al., 2002). Pike is targeted by commercial fishers using mainly gillnets (Abdolmalaki, S. pers. comm.). Depending on the size of gillnets used, up to five people are involved, 


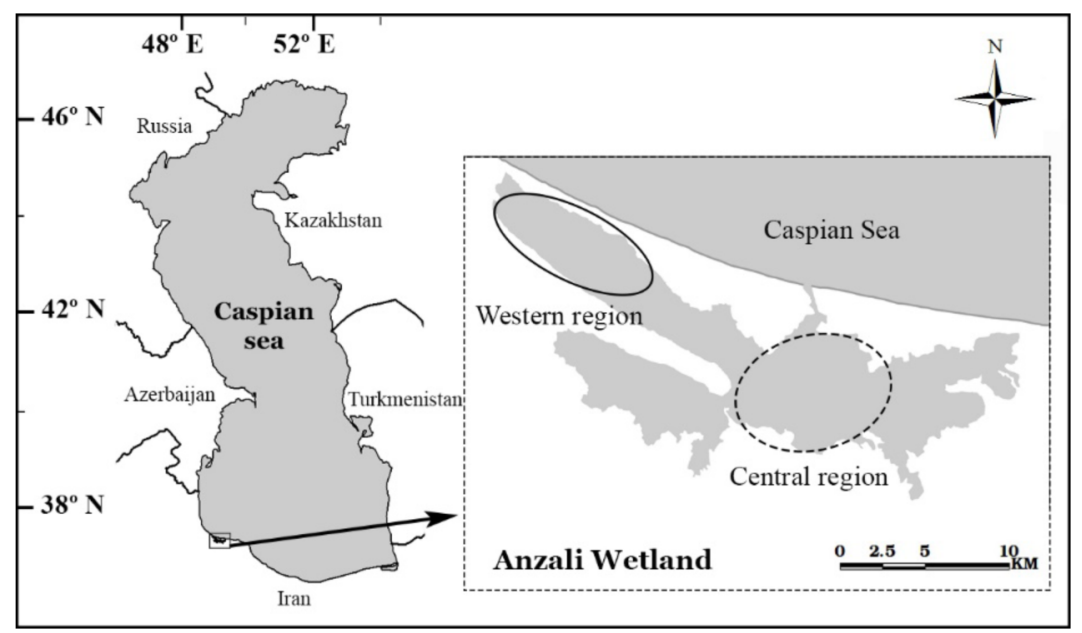

Fig. 1. The western and central study regions of the Anzali Wetland (SW Caspian Sea) where pike samples were collected between July 2012 and June 2013.

fishing at fixed sites. Pike is also captured by a large number of small-scale fisheries, mostly individuals, for consumption and commercial purposes as it is highly valuable. These fishers are distributed all over the wetland with no permanent fishing or landing sites and may occasionally use traps during winter and autumn seasons. The entry of newcomers is not regulated and there are no technical measures or specific requirements (e.g., license, gear or mesh size). Although fishes of all sizes are consumed by the families of fishers, the majority of the total catch is supplied to local and national markets. Unfortunately, there are no official estimates for the contribution of these fisheries to the total catch, but the current small-scale harvest is considered similar to the commercial harvest. Overall, pike is the most important species in official landings (MoslemiAqdam et al., 2014). Despite this importance, pike has not been subject to effective fishery management measures such as fishing closures or legal minimum landing size (MLS) in the Anzali Wetland.

The landing statistics of the Iranian Fisheries National Committee for the Anzali Wetland have shown a steady and substantial decline in pike catches from over 180 tonnes in 2003 to approximately 100 tonnes in 2010 without any notable reduction in fishing effort (Moslemi-Aqdam et al., 2014), leading to concerns about the sustainability of pike fisheries. These concerns are exacerbated due to lack of basic biological and fishery information on which to base management decisions. In this study, we address the lack of life history parameter data for pike in the Anzali Wetland. The studied biological characteristics included the size and age distribution of landed catch, growth rate and length- and age-at-maturity. The stock is assessed using estimates for mortality and yieldper-recruit. This knowledge is essential to support fishery managers in the development of management measures.

\section{Materials and methods}

\subsection{Sampling area and procedure}

The Anzali Wetland $\left(37^{\circ} 22^{\prime}-37^{\circ} 32^{\prime} \mathrm{N}, 49^{\circ} 15^{\prime}-49^{\circ} 36^{\prime} \mathrm{E}\right)$ is connected to the Caspian Sea, and covers an open surface area of about $52 \mathrm{~km}^{2}$ (Pourang et al., 2010) with a catchment area of $3610 \mathrm{~km}^{2}$ (Hargalani et al., 2014). The average low and high water temperature of the Anzali Wetland is in the range 21.6- $28.4^{\circ} \mathrm{C}$ and $5.3-11.4^{\circ} \mathrm{C}$ in summer and winter, respectively (Saemi Komsari et al., 2013). The wetland is shallow with a maximum water depth of $3 \mathrm{~m}$. During the past 50 years, the average water depth has reduced significantly from 10 to $2 \mathrm{~m}$ and decreased to half a meter in some parts (Nazarhaghighi et al., 2014; Mousazadeh et al., 2015). The Anzali Wetland (freshwater with salinity below 0.5) is separated from the Caspian Sea by a dune system; the passage to the sea has a width of $426 \mathrm{~m}$ (Nazarhaghighi et al., 2014). The wetland includes seasonally flooded meadows and is very important both as a spawning ground and nursery area for several fish species (Sakizadeh et al., 2012; Hargalani et al., 2014) especially cyprinids (the most diverse family in the area; Abdoli and Naderi, 1999). While esocids has shown a general tendency to sedentary behavior (Lucas et al., 2001), many studies have shown spawning and feeding migrations of pike in different locations (Koed et al., 2006; Vehanen et al., 2006; Kobler et al., 2008; Pauwels et al., 2014). Samiei et al. (2015) described pike movements within various parts of the Anzali Wetland, but little is known about migration outside the area. However, because pike has not been caught in the Caspian Sea by the Iranian multispecies beach-seine fishery in recent decades, movement or migration between the wetland and the Caspian Sea seems unlikely.

Pike landed by the commercial gillnet fishery $(2.5-12.5 \mathrm{~cm}$ stretched mesh size) were sampled monthly from July 2012 to June 2013 by taking random samples from catches. The sampling was done during the first half of each month and within the western and central regions of the wetland (Fig. 1). The former is deeper $(2.5-3 \mathrm{~m})$ with an open water area of 1900 ha while the latter is shallower $(1 \mathrm{~m})$ with an area of 1214 ha and enormous growth of floating and emergent plants (Mansoori, 2009; Mousazadeh et al., 2015). Considering the inflowing rivers and water level (Hargalani et al., 2014), these two areas are easily accessible and support the main part of the commercial fishery in the Anzali Wetland.

All sampled individuals (total $n=872$ ) from the western $(n=453)$ and central $(n=419)$ regions were measured to the nearest $1 \mathrm{~mm}$ fork length (FL) and weighed (total weight, TW) 


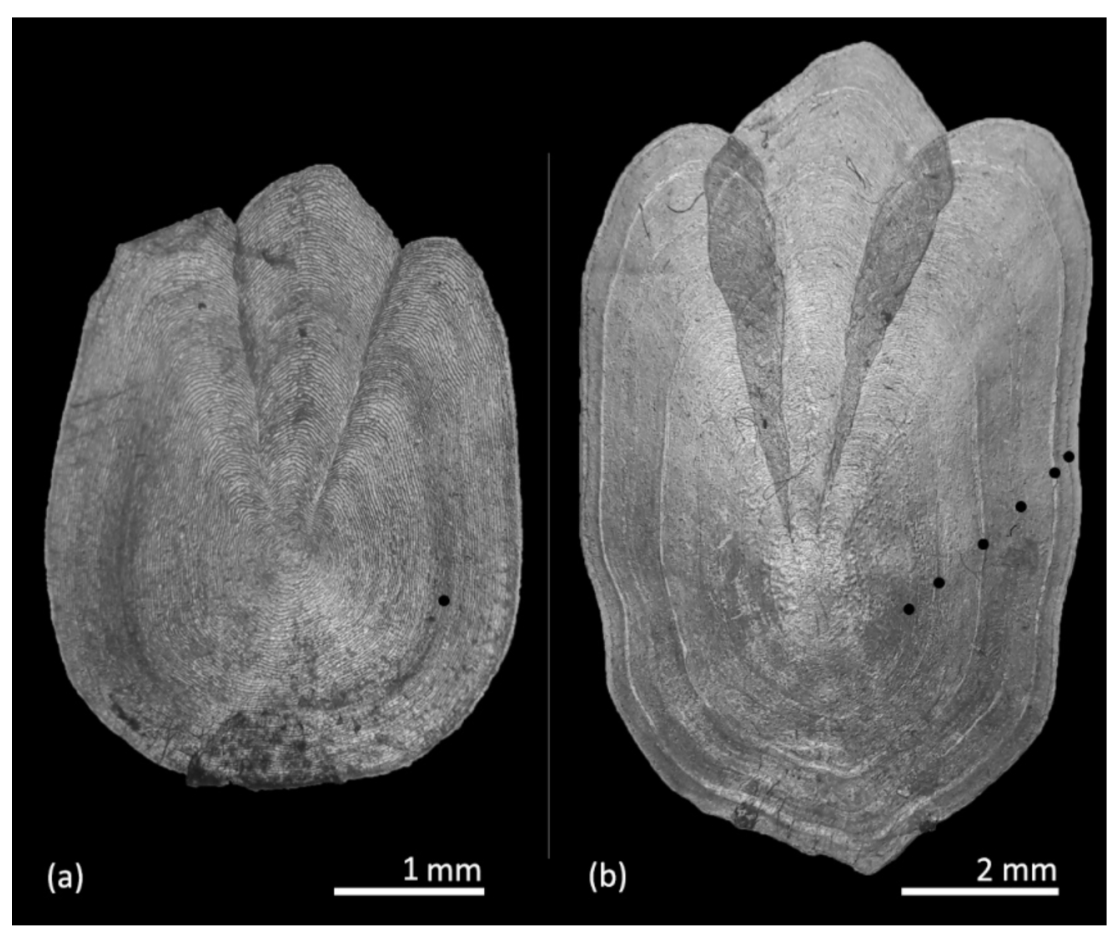

Fig. 2. Pike scales, Anzali Wetland (SW Caspian Sea): (a) 1.62 years ( $F L=28.4 \mathrm{~cm}$, capture date: 12-August-2012), (b) 6.16 years $(\mathrm{FL}=64.7 \mathrm{~cm}$, capture date: 02-March-2013).

to the nearest $0.1 \mathrm{~g}$. Part of the sampled pike (males $n=159$, females $n=257$ ) were taken to the laboratory, where sex was determined by visual inspection of gonads. If the sex could not be determined, histological examination was performed based on West (1990) and Brown-Peterson et al. (2011).

\subsection{Age and growth}

The age of pike can be determined by studying calcified structures such as cleithra, otoliths or scales (Faust et al., 2013; Sauvanet et al., 2013). Several studies have used scales for determining the age of pike (e.g., Mann, 1980; Lorenzoni et al., 2002; Žiliukienè and Žiliukas, 2012; Sauvanet et al., 2013). Scales were used here, because whole, undamaged pike could be sold after the scale sampling. Pike scales were taken from above the lateral line near the rear part of the dorsal fin and prepared for age determination (Roche and Bracken, 1999; Žiliukienè and Žiliukas, 2012). The scales were rapidly washed, cleaned and examined as dry mounts. The reading of large scales was improved by submerging them in a $1 \%$ potassium hydroxide $(\mathrm{KOH})$ solution for 5-10 min, washing in tap water and drying in air (Khan and Khan, 2009). Scales were mounted between two glass slides and examined under transmitted light with the help of a compound microscope (4-10× magnification).

All scales were analyzed without prior knowledge of length or sex. Continuous age was estimated for each pike by counting the annually formed opaque zones and then adding decimals by calculating the number of days from the 1 st of January to the date of capture divided by 365 (Fig. 2). It was assumed that fish caught in December had not yet completed an opaque zone since their last birthday while fish caught in
January had completed an opaque zone (i.e. the winter zone at the edge of the scale was not counted for the former and counted for the latter) (Holden and Raitt, 1974; Kimura and Anderl, 2005). All scales were read twice by the first author, with an interval of about one month between counts. Scale counts that were not in agreement were examined for a third time. In case the third count did not agree with one of the first two counts, the specimen was omitted from the analysis. For further verification, approximately $25 \%$ of the scale samples were randomly chosen for an independent reading by a second expert on fish aging. The accuracy of age estimates between the final readings of the primary reader and the initial readings of the secondary reader was calculated using an index of average percentage error (APE; Beamish and Fournier, 1981) and the coefficient of variation (CV; Chang, 1982):

$$
\begin{gathered}
\mathrm{APE}=\frac{100}{N} \sum_{j=1}^{N}\left[\frac{1}{R} \sum_{i=1}^{R} \frac{\left|x_{i j}-\bar{x}_{j}\right|}{\bar{x}_{j}}\right], \\
\mathrm{CV}=100 \times \frac{\sqrt{\sum_{i=1}^{R} \frac{\left(x_{i j}-\bar{x}_{j}\right)^{2}}{R-1}}}{\bar{x}_{j}},
\end{gathered}
$$

where $N$ is the number of fish aged in the subsample; $x_{i j}$ the $i$ th age determination of the $j$ th fish; $\bar{x}_{j}$ the average age calculated for the $j$ th fish; and $R$ the number of readings. Values below $5 \%$ for APE and CV are indicative of reliable interpretation of age (Morison et al., 1998; Campana, 2001). The estimates of age were also compared between readers by paired sample $t$-tests. Age-frequency distributions of males and females were compared using a Chi-square test. 
Von Bertalanffy growth function (VBGF) curves $L_{t}=L_{\infty}\left(1-\exp \left[-k\left(t-t_{0}\right)\right]\right)$ were fitted to length-at-age data for both regions and sexes separately, where $L_{t}=$ length of fish at age $t, t=$ age, $L_{\infty}=$ theoretical maximum length, $k=$ specific individual growth rate, and $t_{0}=$ theoretical age at zero length (Beverton and Holt, 1957; King, 1995). The VBGF was fitted using a non-linear least squares procedure in SPSS ${ }^{\circledR}$ software, version 16 (IBM, Chicago, IL, USA). The fitted VBGFs were compared between the two regions of the wetland (separately for males and females) across equal size and age ranges using an analysis of the residual sums of squares (ARSS) in which the $F$-statistics comparing the RSS of the two regional models and with the RSS of a single model was calculated (Chen et al., 1992). This was also done for males and females (regions combined). However, Živkov et al. (1999) showed that direct comparisons between VBGF parameters may lead to erroneous conclusions and recommended the comparison of estimated length-at-age of a common range of ages instead of a comparison of the growth parameters, as a more simple and precise method. Hence, in the present study the growth comparisons between two regions or sexes were analyzed by length-at-age differences using the Mann-Whitney $U$ test.

The length and weight relationship was fitted by non-linear regression TW $=a \times \mathrm{FL}^{b}$, where TW is the total weight $(\mathrm{g})$ and FL is the fork length $(\mathrm{cm})$. The maximum theoretical weight $\left(W_{\infty}\right)$ was calculated subsequently as $W_{\infty}=a \times \mathrm{FL}_{\infty}{ }^{\mathrm{b}}$.

\subsection{Length and age at sexual maturity}

Length and age at $50 \%$ sexual maturity $\left(L_{50}\right.$ and $\left.A_{50}\right)$ were determined through the examination of males $(n=96)$ and females $(n=103)$ collected during the spawning period. In the Anzali Wetland pike spawn from February to March (unpublished data). The onset of maturity was analysed using two logistic regression models either with length or age as independent variable: $P($ mature $)=\exp (\alpha+\beta L) \times$ $[1+\exp (\alpha+\beta L)]^{-1}$, where 0 codes non-mature fish and 1 mature fish; $\alpha$ and $\beta$ are the parameters of the logistic regression; and $L$ is the fork length in $\mathrm{cm}$. Similarly, for estimating $A_{50}$, age (in years) was substituted for length in the above equation. To compare estimates with the published values, a conversion from FL to total length (TL) was used when appropriate (Moslemi-Aqdam et al., 2014): $\mathrm{TL}=0.415$ +1.043 FL. All statistical analyses were performed using SPSS $^{\circledR}$ software, version 16 (IBM, Chicago, IL, USA) with at significance level $p \leq 0.05$.

\subsection{Mortality and yield-per-recruit}

Total mortality $(Z)$ was estimated from the age-based catch curve (Beverton and Holt, 1957; Ricker, 1975). For this a linear regression was fitted to the log-transformed relative frequencies in each age class for ages 2-8 years. Age 2 was chosen as the starting age because it was the most abundant age class present. Fishing mortality $(F)$ was then estimated by subtracting natural mortality $(M)$ from $Z$, and current exploitation rate $(E)$ was calculated as $E=F / Z$. Both $F$ and $E$ were calculated for different estimates of $M$ (see below). Annual mortality $(A)$ and apparent survival $(S)$ were then estimated as $A=1-e^{-z}$ and $S=1-A$, respectively.
The yield-per-recruit curve (YPR) was fitted to the agebased model (Thompson and Bell type) (Ricker, 1975). The YPR analyses were undertaken using both size-independent (Pauly, 1980) and size-dependent (Gislason et al., 2010) estimates of natural mortality. In Pauly's (1980) method, $M$ is estimated as: $\log M=-0.0066-0.279 \times \log L_{\infty}+0.6543 \times$ $\log k+0.4634 \times \log T$, where $L_{\infty}$ and $k$ are the parameters of the VBGF and $T$ is the mean annual surface temperature. For Anzali Wetland $T=17.4^{\circ} \mathrm{C}$ was used based on surface water temperature measurements taken during the sampling period approximately every hour on the half-meter water depth near the central coast of the wetland by the Iranian Department of Environment (DoE), Guilan province. Gislason et al. (2010) derived the equation: $\ln (M)=0.55-1.61 \ln (L)+1.44 \ln$ $\left(L_{\infty}\right)+\ln (k)$, where $L_{\infty}$ and $k$ are VBGF parameters and $L$ is the body length $(\mathrm{cm})$. Here $L$ was estimated as the mean length of each age group.

The change in YPR under three different management options for MLS was explored: (i) no MLS, current regime in the Anzali Wetland; (ii) a MLS of $35 \mathrm{~cm} \mathrm{FL} \mathrm{(} \sim$ length at $50 \%$ maturity); and (iii) a MLS of $42 \mathrm{~cm}$ FL (both sexes mature). For each management option YPR was calculated based on 1000 recruits fully recruited to fishing. For option (i) this included ages 2-8, while options (ii) and (iii) included ages larger than the corresponding MLS (Table 3). Two reference points were used to assess the status of pike population in the study region (Pauly, 1984; Cubillos et al., 2002): $F_{0.1}$, the fishing mortality rate at which the marginal increase in YPR is $10 \%$ of that at $F=0$, and $F_{\mathrm{MSY}}$, the fishing mortality rate that gives the maximum sustainable yield (MSY).

\section{Results}

\subsection{Age, growth and maturity}

Pike lengths in the sampled landed catch ranged from 15.4 to $75.4 \mathrm{~cm} \mathrm{FL} \mathrm{(52.9} \mathrm{to} 3462.5 \mathrm{~g} \mathrm{TW})$. The length-weight relationship was $W=0.007 \times \mathrm{FL}^{3.08}\left(r^{2}=0.98\right.$; S.E. $(a)=0.002$ and S.E. $(b)=0.074)$. The precision of re-reading scales was $94.5 \%$ for the primary reader and $84.7 \%$ agreed between the two readers. Most of the disagreements (13\%) differed by \pm 1 year, while $2.3 \%$ differed by \pm 2 year between the two readers. There was no significant difference in the age estimates between the two readers $(t=-1.07, \mathrm{df}=214$, $p=0.287)$. The values of APE (1.1) and CV (3.21\%) indicated that the accretion structure had a suitable reading quality (Morison et al., 1998; Campana, 2001).

The chi-square test showed no significant difference the age-frequency distribution for males and females $\left(\chi^{2}=1.06\right.$, $\mathrm{df}=6, p=0.983)$. Individuals aged 2 years made up highest proportion in the catches of both regions ( 43\%), with approximately $95 \%$ of the catch being below 4 years old (Table 1). Eight-year-old pike were only present in the western region (Fig. 3). Lengths-at-age for males or females were not significantly different between the two sampling regions $(p>0.05$, in all cases). No significant differences were observed in VBGF parameters between the two regions, neither for males $\left(F_{(3,153)}=0.145, p=0.932\right)$, nor females $\left(F_{(3,251)}=1.972, p=0.119\right)$. Therefore, the data from two sampling areas were pooled for subsequent analyses. 
M. Moslemi-Aqdam et al.: Aquat. Living Resour. 2017, 30, 3

Table 1. Length-at-age data for all pike sampled in the Anzali Wetland (SW Caspian Sea) between 2012 and 2013.

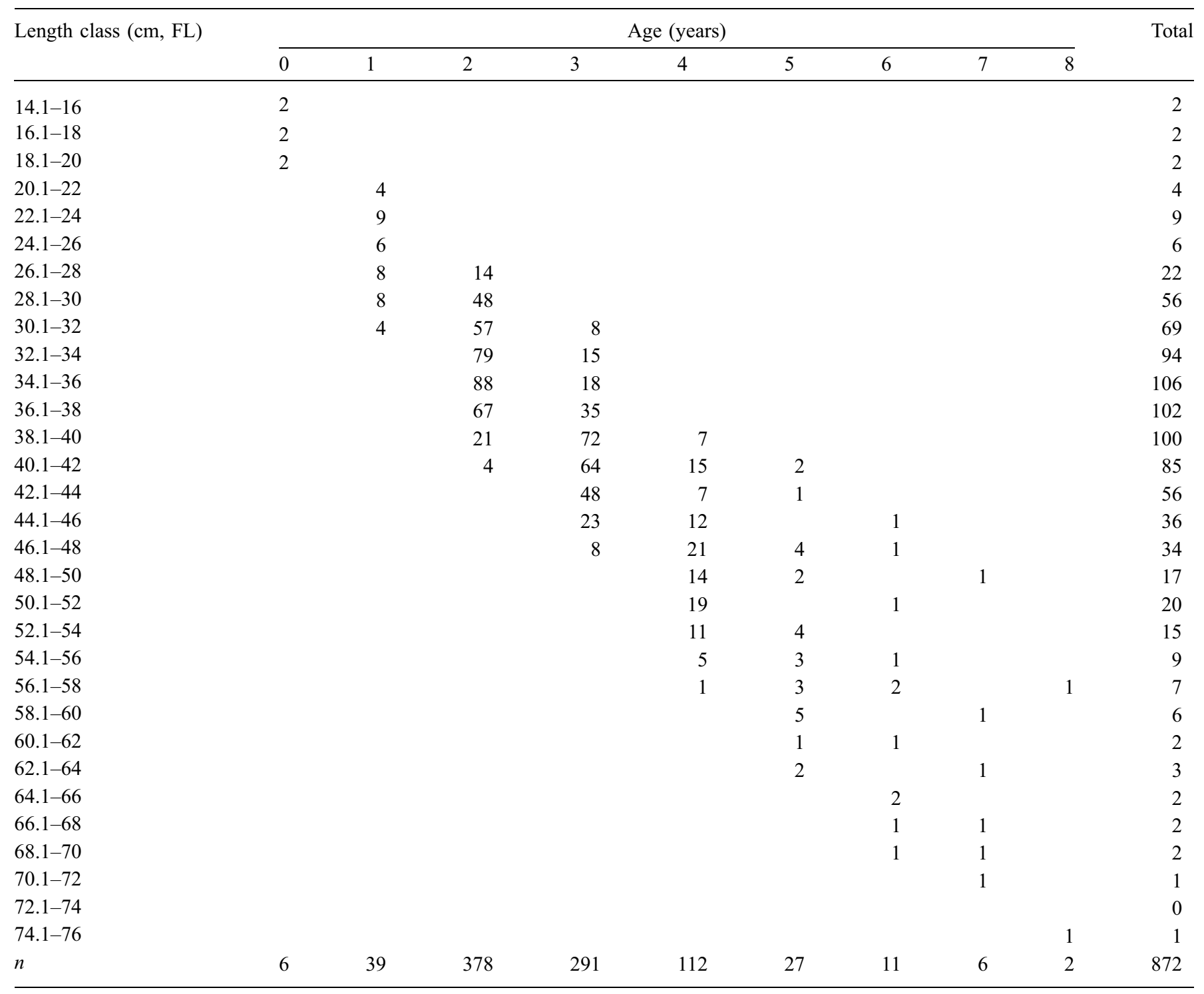

Significant sexual dimorphism was found for ages 2-4 $(p<0.001)$ which was confirmed by the results of the ARSS indicating significantly different growth curves $\left(F_{(3,408)}=3.73, p=0.011\right)$; females reached a larger asymptotic length than males (Fig. 3). Estimated $L_{\infty}$ was $79.8 \mathrm{~cm}$ for males, $95.0 \mathrm{~cm}$ for females, and $90.6 \mathrm{~cm}$ for both sexes combined (Table 2). The largest male measured $55.8 \mathrm{~cm} \mathrm{FL,}$ the largest female $65.3 \mathrm{~cm} \mathrm{FL}$, and the largest unsexed individual pike in the sample $75.4 \mathrm{~cm}$ FL (Fig. 3). Thus, the estimated $L_{\infty}$ values were $43 \%, 49 \%$, and $30 \%$ larger than the largest sampled individual for males, females, and all pike, respectively. While the largest pike sampled was 8 years old, the oldest observed male and female were 6 and 7 years old (Fig. 3). The growth of both sexes combined was described by VBGF parameters $L_{\infty}=90.6 \mathrm{~cm}, k=0.12$ year $^{-1}$ and $t_{0}=-1.74$ year leading to an estimated maximum theoretical weight $W_{\infty}=7465.40 \mathrm{~g}$. There was considerable variation in length at any given age.
Length at $50 \%$ sexual maturity $\left(L_{50}\right)$ was estimated to be $28.6 \mathrm{~cm} \mathrm{FL}$ for male and 33.9 for female pike (Fig. 4). All males $>36 \mathrm{~cm}$ and all females $\geq 42 \mathrm{~cm}$ were mature. Some $(17.7 \%)$ males were mature at age 1 and most $(86.8 \%)$ were mature at age 2 . In contrast, $50 \%$ of females were mature at age $2,85.5 \%$ were mature at age 3 , and $97.2 \%$ were mature at age 4 .

\subsection{Mortality and yield-per-recruit}

Estimated instantaneous total mortality $(Z)$ was 0.93 year $^{-1}\left(r^{2}=0.98\right.$, Fig. 5) corresponding to an annual mortality $(A)$ of $61 \%$ (survival rate $S 39 \%$ ). Natural mortality $M$ estimated from Pauly's (1980) equation was 0.27 year $^{-1}$. Using Gislason et al.'s (2010) equation $M$ was 0.47 year $^{-1}$ for fully recruited pike (age 2) and declined to 0.16 year $^{-1}$ for age 8 (Table 3 ). For pike aged 4 years $($ mean $F L=47.4 \mathrm{~cm}$ ), 

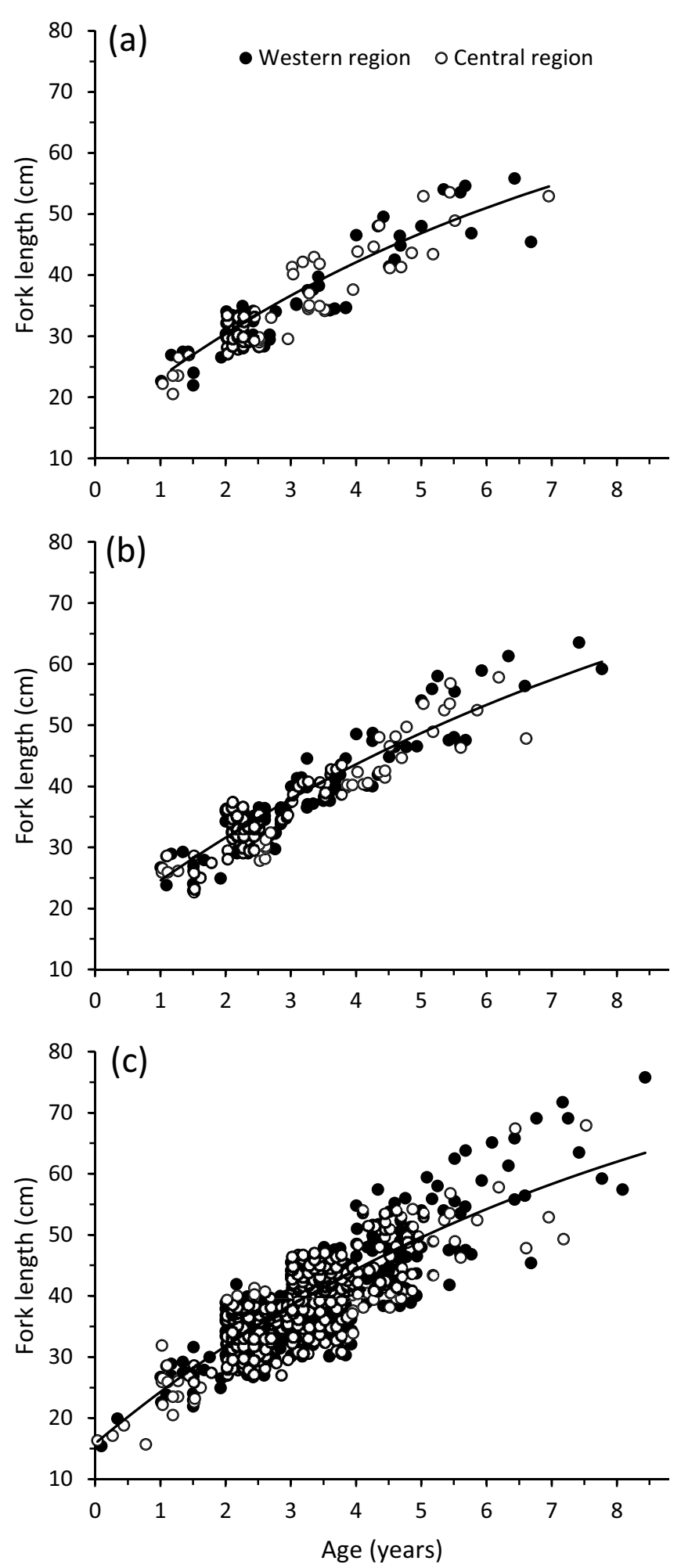

Fig. 3. Length-at-age data for pike with fitted von Bertalanffy growth functions for (a) males $(n=159)$, (b) females $(n=257)$, and (c) all specimens including unsexed $(n=872)$.

the size-dependent estimate of $M$ was the same as the value derived using Pauly's equation $\left(0.27\right.$ year $\left.^{-1}\right)$. Hence, fishing mortality $F$ and exploitation rate $E$ derived from the size-dependent $M$ estimates were small for small fishes and increased for larger pike; for 4 year old individuals the values were equal to those derived from the size-independent equation $\left(F=0.66\right.$ year $^{-1}, E=0.71$ year $\left.^{-1}\right)$.

$Y P R$ estimates were sensitive to $M$ value being used, with yields being larger when the size-independent (Pauly, 1980) $M$ was used, especially in the absence of a MLS (Fig. 6). For both natural mortality estimates, $Y P R$ was greatly increased by the application of a MLS. Under the current management regime (no MLS), $F_{\text {current }}\left(0.66\right.$ year $\left.^{-1}\right)$ exceeded estimated $F_{\text {MSY }}$ ( 0.44 and 0.45 year $^{-1}$ for size-independent and size-dependent $M$, respectively) and the precautionary $F_{0.1} \quad(0.28$ and 0.27 year $^{-1}$ for size-independent and size-dependent $M$, respectively) reference points (Fig. 6a). Furthermore, the shapes of the trajectories were similar in each case. Substantial increase in YPR was observed when setting the MLS to 35 or to $42 \mathrm{~cm} \mathrm{FL} \mathrm{(Fig.} \mathrm{6).} \mathrm{For} \mathrm{the} \mathrm{cases} \mathrm{of} \mathrm{MLS} \mathrm{set} \mathrm{at} 35 \mathrm{~cm} \mathrm{FL}$ (Fig. 6b) or $42 \mathrm{~cm} \mathrm{FL} \mathrm{(Fig.} \mathrm{6c),} F_{\text {current }}$ still exceeded $F_{0.1}$ for both estimates of $M$ (MLS $=35 \mathrm{~cm}: F_{0.1}=0.303$ for constant $M$ and 0.306 for age-specific $M$; MLS $=42 \mathrm{~cm}: F_{0.1}=0.392$ for constant $M$ and 0.373 for age-specific $M$ ), though $F_{\mathrm{MSY}}$ could not be estimated.

\section{Discussion}

\subsection{Growth and maturity}

The results of the present study showed that pike has a similar growth pattern in the two sampling regions, despite the areas selected for sampling having different characteristics especially in terms of depth and presence of aquatic plants. This suggests that pike does not constitute subpopulations in the western and central areas of the Anzali Wetland. Similar growth pattern can be associated with the assumed movement patterns of pike. Migration of pike in various regions of the Anzali Wetland (Samiei et al., 2015), possibly leads to the close contact of individuals and decreases the segregation of phenotypes. Although esocids generally tend to display limited migration (Lucas et al., 2001), many tagging studies have shown that pike have local migration patterns and move more during temperature increase and during spawning time (e.g., Koed et al., 2006; Vehanen et al., 2006; Kobler et al., 2008; Pauwels et al., 2014). As a shallow area with abundant presence of floating and emergent plants, the central region of the Anzali Wetland was expected to have more juveniles. However, the age frequency distribution was similar in both regions (with the dominance of age 2) even though individuals aged 8 years were only observed in the western region. Lucas (1992) stated that where spawning occurs within lake habitats, overall activity increases dramatically and spawning areas may not be distinct from feeding and nursery areas, particularly in small lakes. The observed significant differences of VBGF parameters and length-at-age (ages 2, 3 and 4) between males and females revealed a sexual dimorphism of pike in the Anzali Wetland with greater asymptotic length for females. We acknowledge, however, that our sample sizes were relatively small for estimating growth by sex and that more data, particularly from older fishes, would improve our estimates.

The growth rate ( $k$ parameter of the VBGF) obtained here indicated that growth in the Anzali Wetland is intermediate between northern populations (Lake Rubikiai $55^{\circ} \mathrm{N}$ and Northern Ontario river $49^{\circ} \mathrm{N}$ ), and previously studied southern 
Table 2. Von Bertalanffy growth function (VBGF) parameters with $95 \%$ confidence intervals for pike caught in the Anzali Wetland (SW Caspian Sea) between 2012 and 2013 (combined includes all pike).

\begin{tabular}{lccr}
\hline VBGF parameters & Males $(n=159)$ & Females $(n=257)$ & Combined $(n=872)$ \\
\hline Growth rate $(k)$ & $0.14(0.091$ to 0.189$)$ & $0.11(0.081$ to 0.139$)$ & $0.12(0.086$ to 0.154$)$ \\
Asymptotic length $\left(L_{\infty}\right)$ & $79.83(50.458$ to 109.202$)$ & $94.95(79.135$ to 110.765$)$ & $90.60(69.162$ to 112.038$)$ \\
Age at zero length $\left(t_{0}\right)$ & $-1.55(-2.134$ to -0.966$)$ & $-1.85(-2.149$ to -1.561$)$ & $-1.74(-2.102$ to -1.378$)$ \\
\hline
\end{tabular}
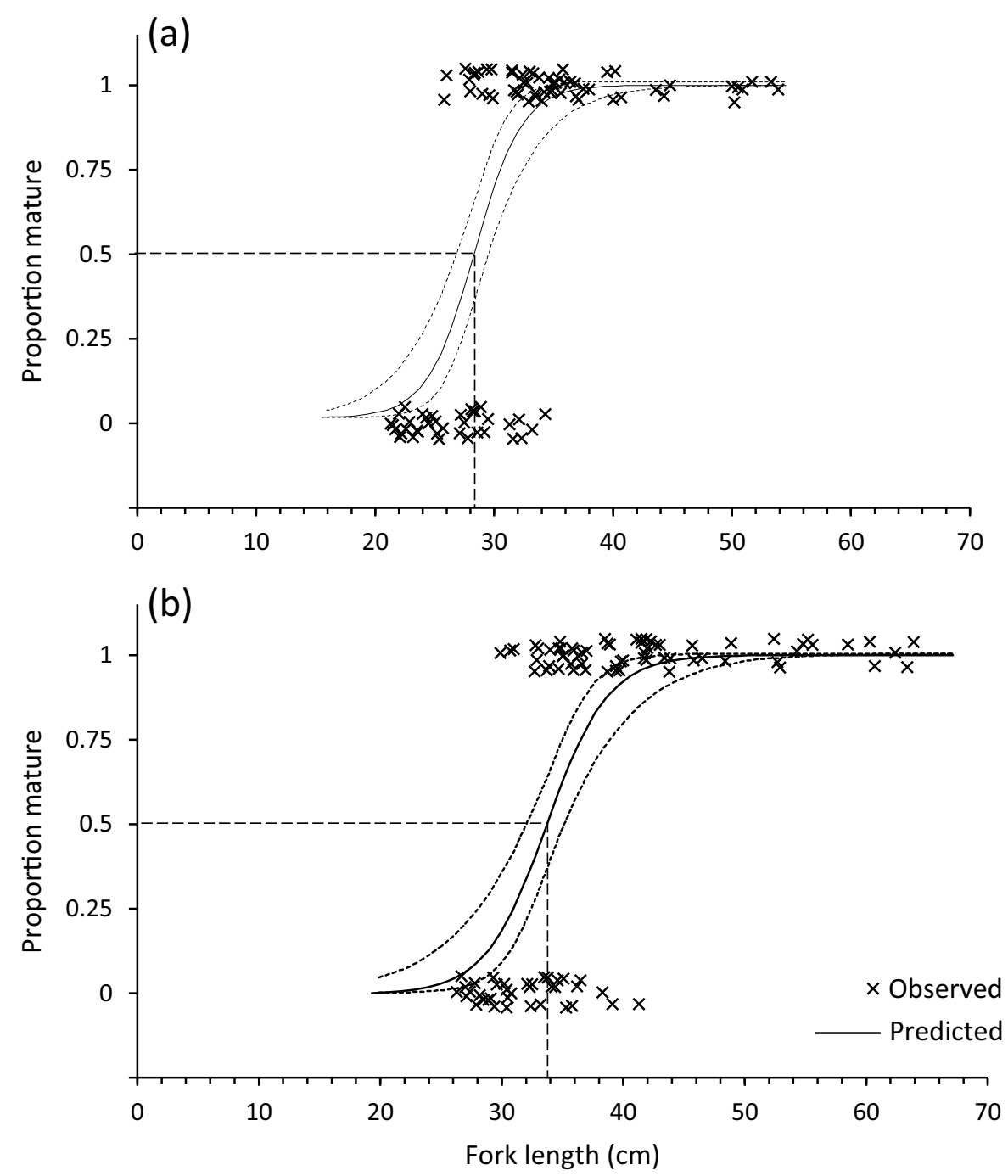

Fig. 4. Maturity ogive for pike with $95 \%$ confidence limits (dotted lines) for (a) males $(n=96)$, and (b) females $(n=103)$. Markers are jittered and the dashed lines indicate the length at $50 \%$ maturity $\left(L_{50}\right)$.

populations (Pactola Reservoir $44^{\circ} \mathrm{N}$, Lake Trasimeno $43^{\circ} \mathrm{N}$, and Lake Karamik $38^{\circ} \mathrm{N}$ ) (Table 4). Diana (1987) and Koch and Steffensen (2013) suggested that marginal habitat conditions may decrease growth and the size structure of pike. As a coolwater, mesothermic species, pike has been documented to be particularly sensitive to growth stunting due to high temperature (Diana, 1987), which is probably the reason for low the growth rate of pike in the Anzali Wetland $\left(37^{\circ} \mathrm{N}\right)$ and other southern populations.

Furthermore, the slightly faster growth rate observed here compared with other southern populations (Table 4) can possibly be attributed to heavy exploitation and high fishing pressure on the Anzali Wetland. If growth is strongly densitydependent, high fishing mortality should increase the growth rate due to lower population density, as found elsewhere (Diana, 1987; Margenau et al., 1998; Pierce and Tomcko, 2005), although such density-dependence is not always found (Mann, 1980; Paukert and Willis, 2003). Many studies have attributed life history shifts in fished populations to high exploitation, including in the case of pike (Diana, 1983), Atlantic cod (Gadus morhua) (Hutchings, 2005) and European hake (Merluccius merluccius) (Hidalgo et al., 2009). 


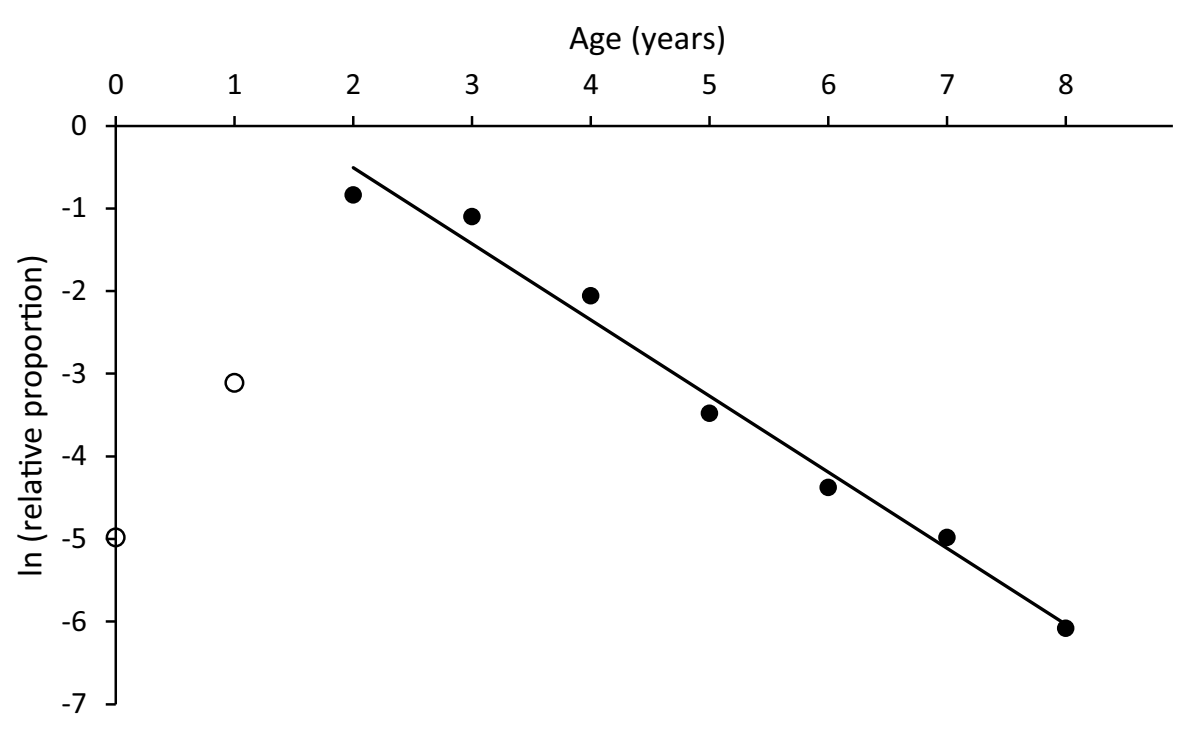

Fig. 5. Fitted catch curve (slope corresponds to instantaneous rate of total mortality) and averaged relative proportions-at-age for pike sampled from commercial catches from the Anzali Wetland (SW Caspian Sea) between 2012 and 2013. Open circles indicate ages that were excluded from the analysis.

Table 3. Size-independent (Pauly, 1980) and size-dependent (Gislason et al., 2010) natural mortality $(M)$ and corresponding fishing mortality $(F)$ and exploitation rate $(E)$. Total mortality $(Z)$ was calculated from an age-based catch curve (Fig. 5). * Theoretical $M$ values, YPR estimations were started from fully recruited age groups (Fig. 5).

\begin{tabular}{lrlll}
\hline \multirow{2}{*}{-estimate } & \multirow{2}{*}{ Age } & \multicolumn{3}{c}{ Parameters } \\
\cline { 3 - 5 } & & $M$ & $F$ & $E$ \\
\hline Pauly (1980) & $2-8$ & 0.27 & 0.66 & 0.71 \\
Gislason et al. (2010) & 0 & $1.40^{*}$ & & \\
& 1 & $0.72^{*}$ & & \\
& 2 & 0.47 & 0.46 & 0.50 \\
& 3 & 0.35 & 0.58 & 0.63 \\
& 4 & 0.27 & 0.66 & 0.71 \\
& 5 & 0.23 & 0.7 & 0.75 \\
& 6 & 0.19 & 0.74 & 0.79 \\
& 7 & 0.17 & 0.76 & 0.82 \\
& 8 & 0.16 & 0.77 & 0.83 \\
\hline
\end{tabular}

The oldest pike caught in the present study was 8 years old, which is a lower maximum age than regularly found in northern populations. The reason for this could be high fishing mortality. The scarcity of large specimens in the present study and previously studied southern populations (Table 4) can produce unrealistic estimates of the VBGF parameters (Pauly, 1979). Živkov et al. (1999) recommended the comparison of length-at-age of a common age range instead of those of the VBGF parameters. Following this approach, comparing the mean length-at-age of ages 2, 3 and 4 (the most common age groups in the present study) with other studies, our estimates were similar to, or even greater than those found elsewhere, even though our estimate of $L_{\infty}$ was the lowest reported (Table 4). Different values of the von Bertalanffy growth parameters can be calculated from similar mean length-at-age using different methods (Landa et al., 2015). Typically, comparative studies of population growth have relied on the use of indices, usually $L_{\infty}$ and $k$, which may be misleading (Živkov et al., 1999).

Our study revealed that females matured at greater lengths and ages than males, which is similar to the conclusions of previous studies (Fig. 7). The estimates of length at $50 \%$ maturity $\left(L_{50}\right)$ of pike in the Anzali Wetland were lower than those previously reported for pike from higher latitudes (Fig. 7). Males in our study matured at 1-2 years of age and females at 2-3 years, whereas the corresponding ages were 2-3 and 3-4 years in the Rybinsk Reservoir (Permitin, 1959: see Raat, 1988) and 4 and 5 years in Lake Lacha (Koz'min, 1980) for males and females, respectively. Fish maturity can be influenced by a number of factors including size, age, geographical distribution, latitudes and fishing mortality (Roff, 1981; Rijnsdorp, 1993; Bromley, 2000; Heino and Godø, 2002). The variation of $L_{50}$ is most likely due to differences in growth rate across latitudes, which has also been reported for many other fish species (e.g., Vila-Gispert et al., 2002; Abookire and Macewicz, 2003; Morita and Nagasawa, 2010). The larger values of length and age at $50 \%$ maturity in higher latitudes correspond to faster growth rates (Abookire and Macewicz, 2003); likewise, in Anzali Wetland the growth rate is slower, as previously discussed, and $L_{50}$ and $A_{50}$ are reached at a smaller size and a younger age.

Alternatively, length- and age-at-maturity could be connected to high fishing pressure, seen in landing statistics and high fishing mortality in the Anzali Wetland (MoslemiAqdam et al., 2014). Especially selective fishing with gill nets can cause reduction in length-at-maturity (Rijnsdorp, 1993; Heino and Godø, 2002). As a biological response to exploitation, decrease in length- and age-at-maturity is widely documented in several fish species (Hood and Johnson, 2000; Hannah et al., 2002; Balik et al., 2006; Hou et al., 2008; Neuheimer and Taggart, 2010) including pike (Carlson et al., 2007). Overall, our estimates of $L_{50}$ were much closer to the heavily exploited southern population of pike from Karamik 

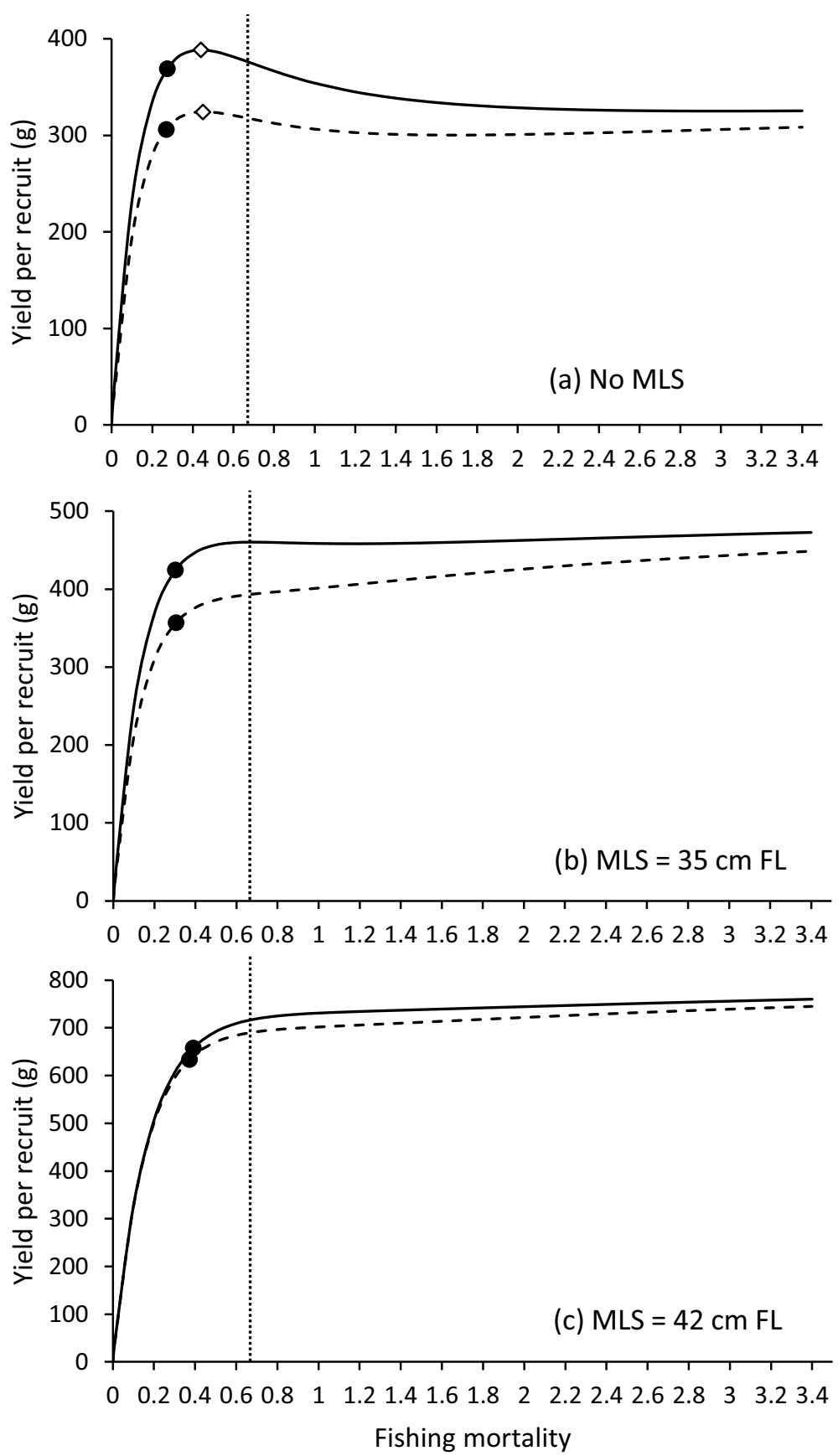

Fig. 6. Yield-per-recruit curves for pike in the Anzali Wetland (SW Caspian Sea) using a size-independent natural mortality estimate (solid line) and a size-dependent estimate (dashed line) for three management scenarios. (a) No minimum landing size (MLS), (b) MLS $=35 \mathrm{~cm}$ FL and (c) $\mathrm{MLS}=42 \mathrm{~cm}$ FL. Black circles are $F_{0.1}$, white squares are $F_{\mathrm{MSY}}$ and the vertical dotted lines indicate the estimated current level of fishing mortality. Note different $y$-axis scales for different MLS scenarios. $F_{\mathrm{MSY}}$ could not be estimated for scenarios (b) and (c).

Lake (Fig. 7). Moreover, several other factors than growth or fishing can influence the life history of fish, including habitat quality (Rypel et al., 2006; Rypel, 2012), feeding regime (Newman and Dunk, 2002), genetic effects (Silverstein et al., 1999) and methodology used (Hou et al., 2008) that can vary both spatially (Brandt et al., 1992) and temporally (Pereira et al., 1995).

\subsection{Stock status and management implications}

The estimate for total mortality $\left(0.93\right.$ year $\left.^{-1}\right)$ is high for a species with the life-history characteristics of pike (i.e., female maturing at 2-3 years of age and a potential longevity of $>10$ years). The obtained fishing mortality $\left(0.66\right.$ year $\left.^{-1}\right)$, exploitation $\left(0.71\right.$ year $\left.^{-1}\right)$ and survival $(39 \%)$ rates suggest that pike is 
Table 4. Biogeographic comparison of population parameters for pike. For this study fork length was converted to total length. * The length-atage data are based on observed values except for the Pactola Reservoir (age-length key) and the Lake Trasimeno (back-calculation method).

\begin{tabular}{|c|c|c|c|c|c|c|}
\hline Parameters & \multicolumn{6}{|c|}{ Study area } \\
\hline Avg. Ann. T. $\left({ }^{\circ} \mathrm{C}\right)$ & 5.8 & 1.2 & 8.7 & 13.1 & 14 & 17.4 \\
\hline Mean depth $(m)$ & 5.7 & - & 19 & 4.7 & $2-3$ & $1-3$ \\
\hline Total mortality $(Z)$ & 0.45 & 0.49 & 0.56 & - & 1.28 & 0.96 \\
\hline \multicolumn{7}{|c|}{ VBGF parameters } \\
\hline$L \infty$ & 131.7 & 98.4 & 152 & 162.7 & 127.2 & 94.9 \\
\hline$k$ & 0.15 & 0.13 & 0.08 & 0.09 & 0.09 & 0.12 \\
\hline$t_{0}$ & -0.40 & -0.16 & -0.25 & -0.29 & -0.37 & -1.39 \\
\hline Aging material & Scale & Pectoral fin ray & Cleithral & Scale & Scale & Scale \\
\hline Reference & $\begin{array}{l}\text { Žiliukiené and } \\
\text { Žiliukas (2012) }\end{array}$ & $\begin{array}{l}\text { Griffiths et al. } \\
\text { (2004) }\end{array}$ & $\begin{array}{l}\text { Scheibel et al. } \\
(2016)\end{array}$ & $\begin{array}{l}\text { Lorenzoni et al. } \\
(2002)\end{array}$ & $\begin{array}{l}\text { Çubuk et al. } \\
\text { (2005) }\end{array}$ & Present study \\
\hline
\end{tabular}

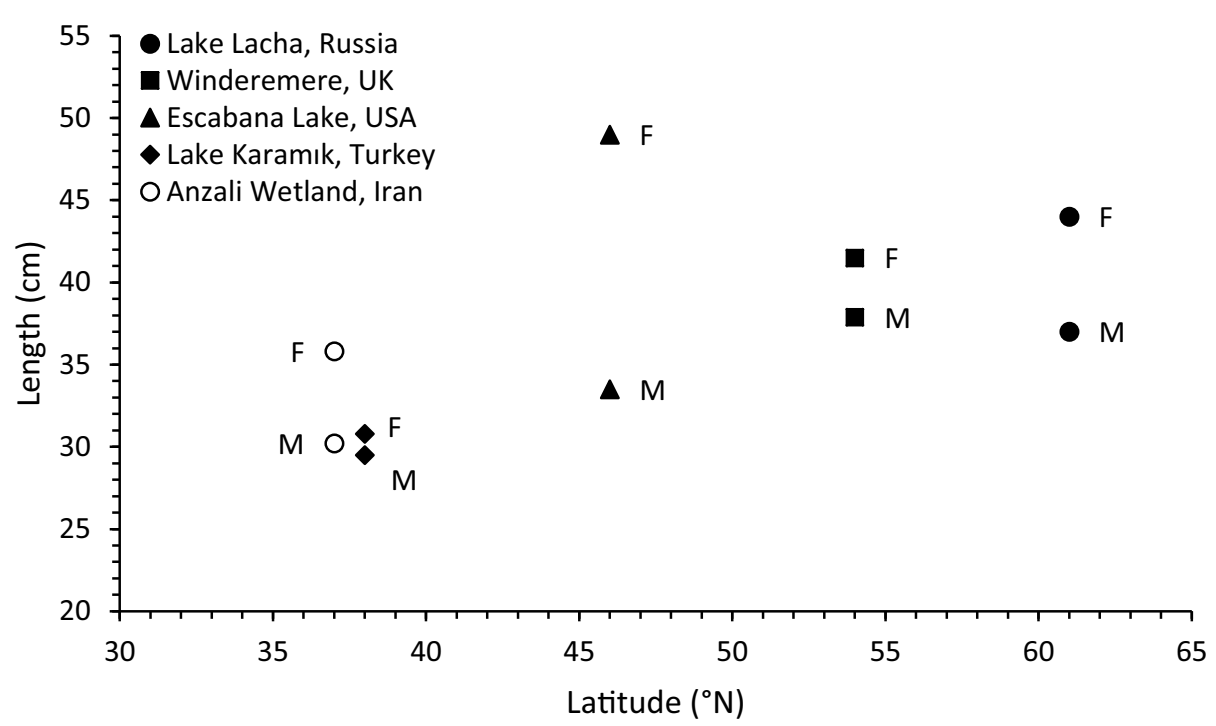

Fig. 7. Length at $50 \%$ maturity $\left(L_{50}\right)$ reported in the literature for pike at different latitudes. Open circles denote data from Anzali Wetland (present study). Source data: Frost and Kipling (1967) (UK); Kempinger and Carline (1978) (USA); Koz'min (1980) (Russia); Balik et al. (2006) (Turkey).

overexploited in the Anzali Wetland. Gulland (1983) suggested that, as a rule of thumb, a fish stock is optimally exploited at a level of $F$, such that $E=0.5$, where $F_{\text {optimum }}=M$. However, MacCall (2009) claimed that fishery experience shows that this $F$ often tends to be high and developed a more general form as $F_{\mathrm{MSY}} \approx 0.4 \times M$. Our results were closer to those reported for the overexploited pike population in Karamik Lake, Turkey (Çubuk et al., 2005, $Z=1.28$ year $^{-1}$, $F=1.09$ year $^{-1}$, and $S=12 \%$ ) than those of the lightly exploited population in Rubikiai Lake, Lithuania (Žiliukiene and Žiliukas, 2012, $Z=0.45$ year $^{-1}$ and $S=0.74 \%$ ).
Natural mortality $(M)$ is difficult to estimate directly (Vetter, 1988; Brodziak et al., 2011) and several empirical models are used to estimate it (Simpfendorfer et al., 2005; Gislason et al., 2010). Many of these empirical relationships assume $M$ to be constant across all age groups. One of the most commonly used models is Pauly's (1980) method. However, later theory and empirical studies indicate that $M$ scales with body size (McCoy and Gillnoy, 2008; Gislason et al., 2010; Brodziak et al., 2011). While the assumption of a constant $k$ may be a valid approximation when only mature individuals are targeted by the fishery, size dependence should be taken 
into account when immature individuals are caught (Brodziak et al., 2011). In addition, as the population biology of pike is influenced by a range of both intrinsic (e.g., cannibalism) and extrinsic (e.g., temperature, food availability, spawning habitat availability, water condition) factors (Craig, 1996; Winfield et al., 2008), natural mortality should be lower in adults than in juveniles. Thus, these size-dependent models seem to be more appropriate for a species with a wide range of body sizes such as pike. As expected, YPR in our study was highly influenced by natural mortality, showing decreasing yields with increasing values of $M$ as observed also earlier (Silberschneider et al., 2009; Fry and Griffiths, 2010). Because pike juveniles were abundant in the present study and the size-dependent $M$ equation (Gislason et al., 2010) tends to give larger $M$ values for juveniles than adults, $Y P R$ values were lower when the sizedependent $M$ was used. On the other hand, when a management measure of MLS with $35 \mathrm{~cm}$ FL or MLS with $42 \mathrm{~cm}$ FL was applied, the differences between methods decreased. This is associated with the more similar natural mortality estimates between size-independent and size-dependent methods in larger size classes. However, according to the wide size range of pike sampled during the present study and factors contributing to the population biology of this species such as cannibalism, food availability and water condition (Craig, 1996; Winfield et al., 2008), size-dependent natural mortality should be more appropriate here. Moreover, we are confident that the observed age composition of pike is representative for the whole Anzali Wetland, because no migration or movement of pike has been noted between Wetland and the Caspian Sea, and the sampling was done in two regions of the Wetland from a wide range of mesh sizes.

The yield-per-recruit analyses indicated that pike in the Anzali Wetland is overfished, with fishing mortality approximately $45 \%$ higher than mortality for the maximum sustainable yield $\left(F_{\mathrm{MSY}}\right)$. Further, the age structure of pike caught in the commercial fishery was dominated by fish aged $\leq 3$ years $(82 \%)$. Notably, pike was estimated to be mature at age 2-3. Therefore, a large part of commercial catches are pike that have not yet spawned and thus, the pike population in the Anzali Wetland may be growth-overfished. Substantial declines in reported commercial landing, the near absence of fish $>5$ years old in landings, and that $Y P R$ is well above the accepted threshold for sustainably, are all concerning. The estimated growth overfishing status of the pike stock in the southwest of the Caspian Sea highlights the need for immediate management action to promote a recovery of this stock and to minimize the risks of possible stock collapses.

Currently, no management measures are applied to the pike fisheries in the Anzali Wetland. A reasonable conclusion of the present study is that fishing pressure is reducing the productivity of the fishery through growth overfishing. A common strategy for reducing the catch of small fish is to change the size selectivity of the fishing gear to be selective for larger fish and ultimately increase the length at first capture (King, 1995). The results show that a substantial increase in YPR could be expected by increasing the length at first capture. Thus, one simple management option would be the implementation of MLS of at least $35 \mathrm{~cm} \mathrm{FL}$, approximately corresponding to the length at $50 \%$ maturity in females, which would: (i) provide greater protection of juveniles to enable reproduction before being caught; (ii) address the issue of growth overfishing; and (iii) increase the biological sustainably of pike fishery in the southwest of the Caspian Sea. However, like in other areas, the enforcement of a size limit could prove difficult because of the inherent characteristics of small scale fisheries (Isaac and Ruffino, 1996; Griffiths et al., 2006) and other measures beside such enforced legislation are needed for the success of these actions. Corrêa et al. (2014) proposed that the combination of fishing restriction and financial compensation for fisheries can lead to greater efficiency of such measures and could have important effects on fish stocks.

The permanent closures of nurseries, where most fish are juveniles, might be an appropriate action for growth overfished stocks. Due to the movement properties of pike (Lucas, 1992; Samiei et al., 2015) within the Anzali Wetland, nurseries cannot be distinguished from feeding areas for pike in the western and central regions (observed similar age composition during the present study). Additionally, many widespread small scale fisheries are engaged in the pike fishery in the wetland and rely on this area for income. So, permanent closures seem not to be applicable here.

Rather, it may be appropriate to introduce a license system. A license should be initially allocated to all fishermen, and thereafter, other measures can be tackled including individual catch quotas based on scientific information. These actions along with ancillary measures such as financial compensation for fishers could be more efficient to improve stock status. Additionally, the allocation of licenses will help the implementation of MLS provided that catch by poachers can be prevented. The success of such options is, however, related to the control of fishing and the restriction of selling the undersized pike. In Iran, even though such restrictions are being implemented, the effectiveness of control is limited due to both inadequate resources and lack of fisheries-specific training (Abdolmalaki and Psuty, 2007). Ensuring adequate enforcement and monitoring is vital for the success of these actions. These management measures should improve the long-term sustainability of pike stock in the southwest of the Caspian Sea, and the continued assessments of the fishery for pike would be required to test the effectiveness of any such management measures.

The main factors causing uncertainty to our YPR models were that the data covered a relatively short time-span (one year) and that the natural mortality had to be estimated based on growth parameters and temperature (Pauly, 1980; Gislason et al., 2010). In addition, variation in year-class strength can affect the reliability of total mortality estimates by the catch curve method (Beverton and Holt, 1957; Ricker, 1975). In our data, the correlation coefficient of the catch curve was high (98\%) which implies that the total mortality estimate should be reliable. However, more data spread other several years should be collected to estimate total mortality more accurately. Furthermore, natural mortality was estimated by two different methods (Pauly, 1980; Gislason et al., 2010) that gave quite similar results in the YPR models for larger size classes. This may indicate that the two methods give quite reasonable estimates for natural mortality. Our estimates of natural mortality were close to the estimates for adult pike in other studies: 0.28-0.37 (Haugen et al., 2007) and 0.21-0.27 (Tiainen et al., 2017). The method of Gislason et al. (2010) was developed for marine species but has also been used for freshwater species (Córdoba et al., 2013). 


\section{Conclusion}

This study presents the first estimates of life history traits for pike in the Anzali Wetland at the southern edge of the natural distribution of this species. Marginal habitat conditions and long periods of high water temperature negatively affected pike growth and reduced the stock's ability to withstand the observed high fishing mortality. Maturation at a young age and small size may be seen as a biological response to high fishing mortality. This study indicates that the pike population in the Anzali Wetland is growth overfished and shows that relatively simple management measures would increase the commercial catches, greatly reduce the risk of collapse and clearly improve the long-term sustainability of pike stock in the southwest of the Caspian Sea.

Acknowledgements. The authors are indebted to Inland Waters Aquaculture Research Institute (Bandar-e-Anzali) personnel for their supports, especially Mohamad Reza Nahrevar as a second reader of scales. We express our gratitude to the many commercial fishers who assisted in the collection of samples and allowed us access to catches. We greatly appreciate the constructive comments and suggestions provided by Prof. Terje Odd Sandlund. We also extend our thanks to Ass. Prof. Tom Jilbert for proofreading the English version, M. Sanjide, P. Dalir and M. Masoudi for their collaboration during sampling, and anonymous referees provided helpful comments on an earlier version of the manuscript.

\section{References}

Abdoli A, Naderi M. 1999. Iranian Inland Water Fishes. Isfahan, Iran: Naghshe-Mana Press (in Persian).

Abdolmalaki Sh., Psuty I. 2007. The effects of stock enhancement of pikeperch (Sander lucioperca) in Iranian coastal waters of the Caspian. ICES J Mar Sci 64: 973-980.

Abookire AA, Macewicz BJ. 2003. Latitudinal variation in reproductive biology and growth of female Dover sole (Microstomus pacificus) in the North Pacific, with emphasis on the Gulf of Alaska stock. J Sea Res 50: 187-197.

Balik I, Çubuk H, Özkök R, Uysal R. 2006. Reproduction properties of pike (Esox lucius L., 1758) population in Lake Karamık (Afyonkarahisar/Turkey). Turk J Zool 30: 27-34.

Beamish R, Fournier D. 1981. A method for comparing the precision of a set of age determinations. Can J Fish Aquat Sci 38: 982-983.

Bevelheimer MS, Stein RA, Carline RF. 1985. Assessing significance of physiological differences among three esocids with a bioenergefics model. Can J Fish Aquat Sci 42, 57-69.

Beverton RJH, Holt SJ. 1957. On the dynamics of exploited fish populations. Fishery Investigation. London: Chapman \& Hall.

Bradford M, Hidalgo M, Massutí E, et al. 2009. Population effects and changes in life history traits in relation to phase transitions induced by long-term fishery harvesting: European hake (Merluccius merluccius) off the Balearic Islands. Can J Fish Aquat Sci 66: 1355-1370.

Brandt SB, Mason DM, Patrick EV. 1992. Spatially-explicit models of fish growth rate. Fisheries 17: 23-35.

Brodziak J, Ianelli J, Lorenzen K, Methot RDJ. 2011. Estimating natural mortality in stock assessment applications. U.S. Dep. Commer., NOAA Tech. Memo. NMFS-F/SPO-119.
Bromley PJ. 2000. Growth, sexual maturation and spawning in central North Sea plaice (Pleuronectes platessa L.), and the generation of maturity ogives from commercial catch data. $J$ Sea Res 44: 27-43.

Brown-Peterson NJ, Wyanski DM, Saborido-Rey F, Macewicz BJ, Lowerre-Barbieri SK. 2011. A standardized terminology for describing reproductive development in fishes. Mar Coast Fish 3: $52-70$.

Campana S. 2001. Accuracy, precision and quality control in age determination, including a review of the use and abuse of age validation methods. J Fish Biol 59: 197-242.

Carlson SM, Edeline E, Vøllestad LA, et al. 2007. Four decades of opposing natural and human-induced artificial selection acting on Windermere pike (Esox lucius). Ecol Lett 10: 512-521.

Casselman J. 1978. Effects of environmental factors on growth, survival, activity, and exploitation of northern pike. Am Fish Soc Spec Publ 11: 114-128.

Casselman JM. 1996. Age, growth, and environmental requirements of pike. In: Craig JF, ed. Pike: biology and exploitation. London: Chapman and Hall, pp. 69-101.

Chang WY. 1982. A statistical method for evaluating the reproducibility of age determination. Can J Fish Aquat Sci 39: 1208-1210.

Chen Y, Jackson D, Harvey H. 1992. A comparison of von Bertalanffy and polynomial functions in modelling fish growth data. Can J Fish Aquat Sci 49: 1228-1235.

Córdoba EA, León AVK, Bonilla-Castillo CA, Petrere Junior M, Peláez M, Duponchelle F. 2013. Breeding, growth and exploitation of Brachyplatystoma rousseauxii Castelnau, 1855 in the Caqueta River, Colombia. Neortop Ichthyol 11: 637-647.

Corrêa MA, Kahn JR, Carvalho Freitas CE. 2014. Perverse incentives in fishery management: the case of the defeso in the Brazilian Amazon. Ecol Econ 106: 186-194.

Craig JF. 1996. Pike: Biology and Exploitation. London: Chapman \& Hall.

Crossman EJ. 1996. Taxonomy and distribution. In: Craig JF, ed. Pike: biology and exploitation. London: Chapman and Hall, pp. 1-12.

Cubillos LA, Hernández A, Sepulveda A, Arcos DA. 2002. Equilibrium yield-curve analysis through an analytic agestructured production model: a sensitivity study for the Chilean jack mackerel fishery. Fish Res 54: 395-407.

Çubuk H, Balik İ, Uysal R, Özkök R. 2005. Some biological characteristics and the stock size of the pike (Esox luciusL., 1758) population in Lake Karamık (Afyon, Turkey). Turk J Vet Anim Sci 29: $1025-1031$.

Diana JS. 1983. Growth, maturation, and production of northern pike in three Michigan lakes. Trans Am Fish Soc 112: 38-46.

Diana JS. 1987. Simulation of mechanisms causing stunting in northern pike populations. Trans Am Fish Soc 116: 612-617.

Durieux ED, Meekan MG, Ponton D, Vigliola L. 2009. Temperature, selective mortality and early growth in the short-lived clupeidSpratelloides gracilis. J Fish Biol 74: 921-938.

Faust MD, Breeggemann JJ, Bahr S, Graeb BD. 2013. Precision and bias of cleithra and sagittal otoliths used to estimate ages of northern pike. J Fish Wildl Manag 4: 332-341.

Frost WE, Kipling C. 1967. A study of reproduction, early life, weight-length relationship and growth of pike, Esox lucius L., in Windermere. J Anim Ecol 36: 651-693.

Fry GC, Griffiths SP. 2010. Population dynamics and stock status of cobia, Rachycentron canadum, caught in Australian recreational and commercial coastal fisheries. Fish Manag Ecol 17: 231-239. 
Gislason H, Daan N, Rice JC, Pope JG. 2010. Size, growth, temperature and the natural mortality of marine fish. Fish Fish 11: $149-158$.

Griffiths R, Newlands N, Noakes D, Beamish F. 2004. Northern pike (Esox lucius) growth and mortality in a northern Ontario river compared with that in lakes: influence of flow. Ecol Freshw Fish 13: 136-144.

Griffiths S, Fry G, Van Der Velde T. 2006. Population dynamics and fishery benefits of a large legal size of a pelagic sportfish, the Talang queenfish, Scomberoides commersonnianus, in northern Australia. Fish Res 82: 74-86.

Gulland JA. 1983. Fish Stock Assessment: a manual of basic methods. New York: FAO/Wiley Series on Food and Agriculture.

Hannah RW, Parker SJ, Fruh EL. 2002. Length and age at maturity of female petrale sole (Eopsetta jordani) determined from samples collected prior to spawning aggregation. Fish Bull 100: 711-719.

Hargalani FZ, Karbassi A, Monavari SM, Azar PA. 2014. A novel pollution index based on the bioavailability of elements: a study on Anzali wetland bed sediments. Environ Monit Assess 186: 2329-2348.

Haugen TO, Winfield IJ, Vøllestad LA, Fletcher JM, James JB, Stenseth NC. 2007. Density dependence and density independence in the demography and dispersal of pike over four decades. Ecol Monogr 77: 483-502.

Heino M, Godø OR. 2002. Fisheries-induced selection pressures in the context of sustainable fisheries. Bull Mar Sci 70: 639-656.

Hidalgo M, Massuti E, Guijarro B, et al. 2009. Population effects and changes in life history traits in relation to phase transitions induced by long-term fishery harvesting: European hake (Merluccius merluccius) off the Balearic Islands. Can J Fish Aquat Sci 66: 1355-1370.

Hilborn R, Walters CJ. 1992. Quantitative fisheries stock assessment: choice, dynamics and uncertainty. Rev Fish Biol Fish 2: 177-178.

Holden MJ, Raitt DFS. 1974. Manual of fisheries science. Part 2-Methods of resource investigation and their application. Rome: FAO.

Hood PB, Johnson AK. 2000. Age, growth, mortality, and reproduction of red porgy, Pagrus pagrus, from the eastern Gulf of Mexico. Fish Bull 98: 723-723.

Hou G, Feng B, Lu H, Zhu J. 2008. Age and growth characteristics of crimson sea bream Paragyrops edita Tanaka in Beibu Gulf. $J$ Ocean Univ China 7: 457-465.

Hutchings JA. 2005. Life history consequences of overexploitation to population recovery in Northwest Atlantic cod (Gadus morhua). Can J Fish Aquat Sci 62: 824-832.

Isaac V, Ruffino M. 1996. Population dynamics of tambaqui, Colossoma macropomum Cuvier, in the Lower Amazon, Brazil. Fish Manag Ecol 3: 315-333.

Kempinger JJ, Carline RF. 1978. Changes in population density, growth, and harvest of northern pike in Escabana Lake after implementation of a 22-inch size limit. Tech. Bull. Wisc. Dep. Nat. Resour. 104, 16 p.

Khan MA, Khan S. 2009. Comparison of age estimates from scale, opercular bone, otolith, vertebrae and dorsal fin ray in Labeo rohita (Hamilton), Catla catla (Hamilton) and Channa marulius (Hamilton). Fish Res 100: 255-259.

King M. 1995. Fisheries biology, assessment and management. Oxford: Fishing News Books.

Kimura DK, Anderl DM. 2005. Quality control of age data at the Alaska Fisheries Science Center. Mar Freshw Res 56: 783-789.
Kobler A, Klefoth T, Wolter C, Fredrich F, Arlinghaus R. 2008. Contrasting pike (Esox lucius L.) movement and habitat choice between summer and winter in a small lake. Hydrobiologia 601: $17-27$.

Koch JD, Steffensen KD. 2013. Population characteristics of northern pike in a southern Kansas impoundment. Trans Kans Acad Sci 116: 139-145.

Koed A, Balleby K, Mejlhede P, Aarestrup K. 2006. Annual movement of adult pike (Esox lucius L.) in a lowland river. Ecol Freshw Fish 15: 191-199.

Koz'min A. 1980. The biology of the pike, Esox lucius, from Lake Lacha. J Ichthyol 20: 44-48.

Kuparinen A, Boit A, Valdovinos FS, Lassaux H, Martinez ND. 2016. Fishing-induced life-history changes degrade and destabilize harvested ecosystems. Sci Rep 6: 22245.

Landa J, Rodriguez-Marin E, Luque PL, Ruiz M, Quelle P. 2015. Growth of bluefin tuna (Thunnus thynnus) in the North-eastern Atlantic and Mediterranean based on back-calculation of dorsal fin spine annuli. Fish Res 170: 190-198.

Law R. 2000. Fishing, selection, and phenotypic evolution. ICES J Mar Sci 57: 659-668.

Lorenzoni M, Corboli M, Martin Dörr A, Mearelli M, Giovinazzo G. 2002. The growth of pike (Esox luciusLinnaeus, 1798) in Lake Trasimeno (Umbria, Italy). Fish Res 59: 239-246.

Lucas MC. 1992. Spawning activity of male and female pike, Esox lucius L., determined by acoustic tracking. Can J Zool 70: 191-196.

Lucas MC, Baras E, Thom TJ, Duncan A, Slavík O. 2001. Migration of freshwater fishes. Oxford: Blackwell Science.

MacCall AD. 2009. Depletion-corrected average catch: a simple formula for estimating sustainable yields in data-poor situations. ICES J Mar Sci 66: 2267-2271.

Mann RHK. 1980 The numbers and reproduction of pike (Esox lucius) in two Dorset rivers. J Anim Ecol 49: 899-915.

Mansoori J. 2009. The Avian Community of Five Iranian Wetlands, Miankaleh, Fereidoonkenar, Bujagh, Anzali and Lavandevil, in the South Caspian Lowlands. Podoces 4: 44-59.

Margenau TL, Rasmussen PW, Kampa JM. 1998. Factors affecting growth of northern pike in small northern Wisconsin lakes. $N \mathrm{Am} \mathrm{J}$ Fish Manag 18: 625-639.

McCoy MW, Gillnoy JF. 2008. Predicting natural mortality rates of plants and animals. Ecol Lett 11: 710-716.

Morison AK, Robertson SG, Smith DC. 1998. An integrated system for production fish aging: image analysis and quality assurance. $N$ Am J Fish Manag 18: 587-598.

Morita K, Nagasawa T. 2010. Latitudinal variation in the growth and maturation of masu salmon (Oncorhynchus masou) parr. Can J Fish Aquat Sci 67: 955-965.

Moslemi-Aqdam M, Imanpour Namin J, Sattari M, Abdolmalaki Sh., Bani A. 2014. Length-length, length-weight relationship and relative condition factor of pike, Esox lucius Linnaeus, 1758, in Anzali Wetland (southwest of the Caspian Sea). Casp J Environ Sci 12: 109-117.

Mousazadeh R, Ghaffarzadeh H, Nouri J, Gharagozlou A, Farahpour M. 2015. Land use change detection and impact assessment in Anzali international coastal wetland using multi temporal satellite images. Environ Monit Assess 187: 1-11.

Nazarhaghighi F, Timm T, Nadoushan RM, Shabanipour N, Fatemim MR, Moradi AM. 2014. Oligochaetes (Annelida, Clitellata) in the Anzali International Wetland, north-western Iran. Estonian J Ecol 63: $130-144$.

Nelson JS. 2006. Fishes of the world. New Jersey: John Wiley \& Sons. 
Neuheimer AB, Taggart CT. 2010. Can changes in length-at-age and maturation timing in Scotian Shelf haddock (Melanogrammus aeglefinus) be explained by fishing? Can J Fish Aquat Sci 67: 854-865.

Newman SJ, Dunk IJ. 2002. Growth, age validation, mortality, and other population characteristics of the Red Emperor Snapper, Lutjanus sebae (Cuvier, 1828), off the Kimberley Coast of NorthWestern Australia. Estuar Coast Shelf Sci 55: 67-80.

Neumann RM, Willis DW, Sammons SM. 1994. Seasonal growth of northern pike (Esox Iucius) in a south Dakota Glacial Lake. J Freshw Ecol 9: 191-196.

Newman SJ, Cappo M, Williams DM. 2000. Age, growth, mortality rates and corresponding yield estimates using otoliths of the tropical red snappers, Lutjanus erythropterus, L. malabaricus and L. sebae, from the central Great Barrier Reef. Fish Res 48: 1-14.

Paukert CP, Willis DW. 2003. Population characteristics and ecological role of northern pike in shallow natural lakes in Nebraska. N Am J Fish Manag 23: 313-322.

Paukert CP, Klammer JA, Pierce RB, Simonson TD. 2001. An overview of northern pike regulations in North America. Fisheries 26: 6-13.

Pauly D. 1979. Gill size and temperature as governing factors in fish growth: a generalization of von Bertalanffy's growth formula, $\mathrm{PhD}$ Thesis. Germany: University of Kiel.

Pauly D. 1980. On the interrelationships between natural mortality, growth parameters, and mean environmental temperature in 175 fish stocks. ICES J Mar Sci 39: 175-192.

Pauly D. 1984. Fish population dynamics in tropical waters: a manual for use with programmable calculators. Manila: International Center for Living Aquatic Resources Management.

Pauwels IS, Geothals PLM, Coeck J, Mouton AM. 2014. Movement pattern of adult pike (Esox lucius L.) in a Belgian lowland river. Ecol Freshw Fish 23: 373-382.

Pereira DL, Bingham C, Spangler GR, Conner DJ, Cunningham, PK. 1995. Construction of a 110-year biochronology from sagittae of freshwater drum (Aplodinotus grunniens). In: Secor DH, Dean JM, Campana SE eds. Recent developments in fish otolith research. Columbia, SC: University of South Carolina Press, pp. 177-196.

Pierce RB, Tomcko CM. 2005. Density and biomass of native northern pike populations in relation to basin-scale characteristics of north-central Minnesota lakes. Trans Am Fish Soc 134: 231-241.

Pourang N, Richardson C, Mortazavi M. 2010. Heavy metal concentrations in the soft tissues of swan mussel (Anodonta cygnea) and surficial sediments from Anzali wetland, Iran. Environ Monit Assess 163: 195-213.

Raat AJP. 1988. Synopsis of biological data on the northern pike: Esox lucius Linnaeus, 1758. FAO Fish. Synop. 30 Rev. 2: 1-178.

Ratner S, Lande R. 2001. Demographic and evolutionary responses to selective harvesting in populations with discrete generations. Ecology 82: 3093-3104.

Ricker W. 1975. Computation and interpretation of biological statistics of fish populations. Bull Fish Res Board Can 191: $1-382$.

Rijnsdorp A. 1993. Fisheries as a large-scale experiment on life-history evolution: disentangling phenotypic and genetic effects in changes in maturation and reproduction of North Sea plaice, Pleuronectes platessa L. Oecologia 96: 391-401.

Robertson DR, Ackerman J, Choat JH, Posada JM, Pitt J. 2005. Ocean surgeonfish Acanthurus bahianus. I. The geography of demography. Mar Ecol Prog Ser 295: 229-244.
Roche W, Bracken J. 1999. Some characteristics of a pike Esox lucius L. population in an Irish reservoir. Hydrobiologia 392: 217-223.

Roff DA. 1981. Reproductive uncertainty and the evolution of iteroparity: why don't flatfish put all their eggs in one basket? Can J Fish Aquat Sci 38: 968-977.

Rypel AL. 2012. Meta-analysis of growth rates for a circumpolar fish, the northern pike (Esox lucius), with emphasis on effects of continent, climate and latitude. Ecol Freshw Fish 21: 521-532.

Rypel AL, Bayne DR, Mitchell, JB. 2006. Growth of freshwater drum from lotic and lentic habitats in Alabama. Trans Am Fish Soc 135: 987-997.

Saemi Komsari M, Bani A, Khara H, Reza Esmaeili H. 2013. Reproductive strategy of the European perch, Perca fluviatilis Linnaeus, 1758 (Osteichthyes: Percidae) in the Anzali wetland, southwest Caspian Sea. J Appl Ichthyol 30: 307-313.

Sakizadeh M, Esmaeili Sari A, Abdoli A, Bahramifar N, Hashemi SH. 2012. Determination of polychlorinated biphenyls and total mercury in two fish species (Esox lucius and Carassius auratus) in Anzali Wetland, Iran. Environ Monit Assess 184: 3231-3237.

Samiei MH, Norouzi M, Ravaei A, Behrooz M, Nazemi A. 2015. Genetic structure in anzali wetland's pike (Esox lucius) using microsatellite molecular method. JBES 6: 91-99.

Sattari M, Shahsavani D, Shafei SH. 2002. Systematic ichthyology. Rasht, Iran: Haghshenas Press (in Persian).

Sauvanet J, Bourdier G, Colombet J, Viallefont A, Lemarchand C, Desvilettes C. 2013. Estimating Esox lucius (Esocidae, Esociformes) density and population structure in a large European alluvial river: the Allier (France). J Ichthyol 53: 617-627.

Scheibel NC, Dembkowski DJ, Davis JL, Chipps SR. 2016. Impacts of northern pike on stocked rainbow trout in Pactola Reservoir, south Dakota. N Am J Fish Manag 36: 230-240.

Senanan W, Kapuscinski AR. 2000. Genetic relationships among populations of northern pike (Esox lucius). Can J Fish Aquat Sci 57: 391-404.

Silberschneider V, Gray CA, Stewart J. 2009. Age, growth, maturity and the overfishing of the iconic sciaenid, Argyrosomus japonicus, in south-eastern, Australia. Fish Res 95: 220-229.

Silverstein JT, Wolters WR, Holland M. 1999. Evidence of differences in growth and food intake regulation in different genetic strains of channel catfish. J Fish Biol 54: 607-615.

Simpfendorfer CA, Bonfil R, Latour RJ. 2005. Mortality estimation. In: Musick JA, Bonfil R, eds. Management techniques for elasmobranch fisheries. Rome: FAO Fish. Tech. paper 474, pp. 127-142.

Tiainen J, Olin M, Lehtonen H, Nyberg K, Ruuhijärvi J. 2017. The capability of harvestable slot-length limit regulation in conserving large and old pike (Esox lucius). Boreal Environ Res 22: $169-186$

Tolan JM, Fisher M. 2009. Biological response to changes in climate patterns: population increases of gray snapper (Lutjanus griseus) in Texas bays and estuaries. Fish Bull 107: 36-45.

Vehanen T, Hyvärinen P, Johansson K, Laaksonen T. 2006. Patterns of movement of adult northern pike (Esox lucius L.) in a regulated river. Ecol Freshw Fish 15: 154-160.

Vetter EF. 1988. Estimation of natural mortality in fish stocks: a review. Fish Bull 86: 25-43.

Vila-Gispert A, Moreno-Amich R, Garcia-Berthou E. 2002. Gradients of life-history variation: an intercontinental comparison of fishes. Rev Fish Biol Fish 12: 417-427. 
Walters CJ, Martell SJ. 2004. Fisheries Ecology and Management. New Jersey: Princeton University Press.

West G. 1990. Methods of assessing ovarian development in fishes: a review. Mar Freshw Res 41: 199-222.

Winfield IJ, James JB, Fletcher, JM. 2008. Northern pike (Esox lucius) in a warming lake: changes in population size and individual condition in relation to prey abundance. Hydrobiologia 601: 29-40.
Žiliukienė V, Žiliukas V. 2012. Spawning population characteristics of pike Esox lucius L. in Lake Rubikiai (Lithuania). Cent Eur J Biol 7: 867-877.

Živkov MT, Trichkova TA, Raikova-Petrova GN. 1999. Biological reasons for the unsuitability of growth parameters and indices for comparing fish growth. Environ Biol Fishes 54: $67-76$.

Cite this article as: Moslemi-Aqdam M, Imanpour Namin J, Sattari M, Lappalainen J, Olin M. 2017. Demographic variables and stock status of pike, Esox lucius, in the commercial fishery in the Anzali Wetland (SW Caspian Sea) near the southern limits of its distribution range. Aquat. Living Resour. 30: 3 